\title{
MEKANISME AKSES PADA HAK KEPEMILIKAN DI KESATUAN PENGELOLAAN HUTAN PRODUKSI MERANTI, SUMATERA SELATAN
}

(The Access Mechanism to the Property Rights in Forest Management Unit of Meranti, South Sumatra)

\author{
Ja Posman Napitu ${ }^{1}$, Aceng Hidayat ${ }^{2}$, Sambas Basuni ${ }^{3}$, Sofyan Sjaf ${ }^{4}$ \\ 'Balai Pengelolaan Hutan Produksi Wilayah II Medan Jalan Sisingamangaraja XII No.14 Medan, \\ Sumatera Utara 20217 \\ E-mail: njpnapitu@gmail.com \\ ${ }^{2}$ Departemen Ekonomi Sumber Daya dan Lingkungan, Fakultas Ekonomi dan Manajemen, \\ Institut Pertanian Bogor. Jalan Agatis Wing 3 Lantai 2, Darmaga Bogor \\ E-mail: a.hidayat.esl@gmail.com \\ ${ }^{3}$ Departemen Konservasi Sumber Daya Hutan dan Ekowisata, Fakultas Kehutanan \\ Institut Pertanian Bogor. PO.BOX. 168, Darmaga Bogor \\ E-mail: basuni.sambas@gmail.com \\ ${ }^{4}$ Departemen Sains Komunikasi dan Pengembangan Masyarakat, Fakultas Ekologi Manusia \\ Institut Pertanian Bogor. Gedung FEMA Wing 1 Lantai 5, Darmaga Bogor \\ E-mail: sofyan.sjaf@gmail.comm
}

Diterima 10 Februari 2017, direvisi 22 Mei 2017, disetujui 5 Juni 2017

\begin{abstract}
The interest of various parties on forest utilization access lead to the ambiguity of property rights due to user overlapping. This research explained the ambiguity factors of property rights from access mechanism and its relation to the land conflict. The research using purposive sampling method to obtain data of land use change, documents, historical study, as well as in-depth interviews of 123 people key informant. Rapid Land Tenure Assessment (RaTA) and descriptive analysis method were used to analyze the data. The results showed that both access and property rights theory could explain the overlapping use on forest area in Meranti Forest Management Unit (FMU). Analysis of rights-based access mechanism explained factors within the property rights status and the causes of land overlapping, i.e. the dynamics of management change, boundaries area issues, and lack of control. The factors of land user based on structure mechanism were the kinship ties, patroness system or pesirah, community and religious leaders. The access of structure mechanism have lead to claim of $38.53 \%$ areas of Meranti FMU. Changes of the rules have increased new users and causing overlapping between bussines license holder with community access. The research recommends avoiding change of area management forms, and for involving local communities in determining new users, duration, and profit sharing.
\end{abstract}

Keywords: Access; property rights; rights-based mechanism; structure mechanism.

\begin{abstract}
ABSTRAK
Kepentingan berbagai pihak terkait akses pemanfaatan hutan mengakibatkan ketidakjelasan hak kepemilikan karena tumpang tindih pengguna. Penelitian ini menjelaskan faktor penyebab ketidakjelasan hak kepemilikan dari mekanisme akses dan kaitannya dengan konflik lahan. Peneliti menggunakan teknik purposive sampling untuk mendapatkan data perubahan lahan, dokumen proses tata batas dan kepemilikan lahan, sejarah pengelolan, wawancara mendalam dengan 123 orang tokoh kunci. Analisis data menggunakan Rapid Land Tenure Assessment (RaTA) dan analisis deskriptif. Hasil penelitian menunjukkan bahwa teori akses dan hak kepemilikan dapat menjelaskan tumpang tindih lahan pada wilayah KPHP Meranti. Analisis akses mekanisme hak menjelaskan faktor-faktor perubahan status kepemilikan lahan dan penyebab tumpang tindih lahan, yaitu: a) dinamika perubahan pengelolaan, b) permasalahan batas kawasan, dan c) lemahnya pengawasan. Faktor penyebab pengguna lahan dari mekanisme struktur antara lain: ikatan kekerabatan, pemberian dari pesirah (sistem patrones), dan
\end{abstract}


tokoh masyarakat/pemimpin agama. Akses mekanisme struktur mengakibatkan klaim lahan seluas 38,53\% pada wilayah KPHP Meranti. Perubahan aturan main selalu menimbulkan pengguna baru dan mengakibatkan tumpang tindih pemanfaatan antara pemegang izin usaha dengan akses masyarakat. Rekomendasi dari penelitian ini adalah: a) menghindari perubahan bentuk pengelolaan, dan b) melibatkan masyarakat lokal untuk menentukan siapa pengguna, batas waktu, dan besaran kontribusi pendapatan.

Kata kunci: Akses; hak kepemilikan; mekanisme hak; mekanisme struktur.

\section{PENDAHULUAN}

Pemanfaatan kawasan hutan produksi sebagaimana diatur dalam Pasal 28 dan Pasal 29 pada Undang Undang (UU) Nomor 41 Tahun 1999 Tentang Kehutanan, menjelaskan berbagai bentuk pemanfaatan yang dapat dilaksanakan sesuai aturan perizinan. Perizinan usaha dimaksud dapat diberikan kepada perseorangan, koperasi, swasta, Badan Usaha Milik Negara (BUMN) atau Badan Usaha Milik Daerah (BUMD). Adanya izin pemanfaatan yang diberikan kepada salah satu pihak sesuai aturan yang digunakan (rule in use) akan membatasi hak pemilikan pihak lain (non excludeble), namun tidak dapat membatasi penggunaan lain (non rivalery) (Schalager dan Ostrom, 1992; Suharti, Darusman, Nugroho \& Sundawati, 2016).

Menurut Nugroho (2013) ada dua fungsi pemerintah dalam mengatur pemanfaatan hutan, yaitu pengalokasian dan pendistribusian kawasan hutan produksi. Fungsi alokasi merupakan representasi publik diberi kewenangan kepada pemerintah untuk menetapkan sumber daya apa yang akan dimanfaatkan, untuk apa, dan bagaimana cara pemanfaatannya. Sedangkan fungsi distribusi merupakan alokasi kawasan hutan dapat dimanfaatkan masyarakat, dan negara memperoleh devisa dari pemanfaatan kepada masyarakat dengan prinsip-prinsip keadilan distribusi (redistributional equity) (Larson dan Pulhin, 2012). Kedua fungsi tersebut dituangkan dalam aturan yang digunakan Pasal 28 dan Pasal 29 pada UU Nomor 41 Tahun 1999 dan aturan turunannya Peraturan Pemerintah (PP) Nomor 3 Tahun 2008 jo. PP Nomor 6 Tahun 2007.
Kenyataanya, perbedaan cara pandang pengguna dan inkonsistensi implementasi aturan sering mengakibatkan aturan pemanfaatan menjadi beban (Mulyaningrum, Kartodihardjo, Jaya \& Nugroho, 2013). Perubahan aturan juga dapat mengubah pengguna lama (masyarakat) ke pengguna baru Hutan Tanaman Idustri (HTI), dimana aturan menjadi alat klaim dari akses mekanisme hak. Perubahan menyebabkan konflik antara masyarakat dan pemerintah dan HTI (Mutolib dan Ismono, 2015). Aturan yang digunakan juga dapat mengakibatkan kawasan hutan menjadi subyek ekonomi yang dapat jatuh kepada satu pihak (Sylviani dan Hakim, 2014). Perubahan tersebut terjadi disebabkan bahwa, ada berbagai faktor penyebab, yaitu faktor lingkungan ekonomi, lingkungan politik, lingkungan aturan hukum, lingkungan sosial dan teknologi yang akan mengubah kelembagaan pengatur pemanfaatan sumber daya alam (Dolsak dan Ostrom, 2003). Ketidakjelasan narasi aturan dan inkonsistensi dimana lebih didominasi pemahaman ilmu kehutanan dan mengabaikan pengguna lain, khususnya masyarakat sekitar hutan atau interaksi sosial sering diabaikan (Kartodihardjo, 2013). Tidak adanya peran serta masyarakat dalam pengaturan pemanfaatan, mengakibatkan masyarakat terpisah dari interaksi sosialnya dalam pengelolaan hutan, khususnya dalam mencari kebutuhan kehidupannya sendiri (livelihoods) dengan membentuk akses terhadap kawasan hutan (Ingram et al., 2014).

Menurut Ribot dan Peluso (2003), definisi akses terhadap kawasan hutan merupakan kemampuan pengguna untuk mendapatkan 
manfaat dari hutan. Bentuk akses dapat dibagi menjadi dua yaitu: a) akses mekanisme hak, dan b) akses mekanisme struktur. Akses hak, merupakan terbentuknya akses dari adanya aturan pemanfaatan terkait interaksi dan kepentingan dalam ikatan kekuasaan berupa pemberian izin. Akses mekanisme hak terbentuk dari adanya hukum dan aturan yang mengatur pemanfaatan dan memposisikan pemerintah sebagai regulator bagi pihak yang memiliki otoritas terhadap akses. Akses berdasarkan mekanisme struktur, terbentuk dari adanya hubungan sosial atau kekerabatan di antara sesama pengguna yang umumnya telah ada sebelumnya (Priyatna \& Kinseng, 2013). Mekanisme akses akan dipengaruhi situasi aksi dan faktor eksogen kelembagan yaitu: atribut biofisik, aturan yang digunakan (rule in use) dan atribut komunitas terhadap outcome (Fennell, 2011).

Akses yang tidak terkontrol terhadap kawasan hutan juga menyebabkan degradasi dan deforestasi (Quizon, 2013; Tsujino, Yumoto, Kitamura, Djamaluddin \& Darnaedi, 2016). Akses mekanisme struktur di Indonesia sudah dimulai dari sejarah panjang penggunaan lahan dan sangat terkait dengan atraksi kultur budaya dan adanya hubungan patron-klien di masyarakat, dengan membuka para rimbo yaitu jenis kebun karet hutan (Ministry of Forestry, 2008; Pirard, Petit \& Baral, 2017). Sedangkan mekanisme hak (access base rights mechanism) sudah ada sejak era kolonial hingga saat ini. Menurut Febryano, Suharjito, Darusman, Kusmana \& Hidayat, (2015) penggunaan kawasan hutan di Indonesia saat ini lebih dipahami dari bagaimana kawasan hutan dimanfaatkan sesuai dengan aturan dan hukum yang berlaku atau mekanise hak.

Pengguna kawasan hutan, lebih dilihat pada status legal dan tidak legal yang merupakan prinsip dalam mekanisme hak. Legal yang dimaksud apabila pengguna mendapatkan izin dari Menteri Kehutanan, sedangkan ilegal tidak ada izin atau tidak sesuai dengan aturan. Akses struktur diposisikan berada pada status ilegal karena tidak ada izin penggunaan lahan yang faktanya mereka telah berada di dalam kawasan hutan jauh sebelum lahan tersebut sebagai kawasan hutan. Mekanisme akses hak dan struktur mengakibatkan keragaman pengguna kawasan. Kepentingan para pihak menjadi bias dalam memahami pembentukan Kesatuan Pengelolaan Hutan (KPH) sebagaimana dijelaskan Karsudi, Soekmadi \& Kartodihardjo (2010).

Berbagai kepentingan dan pengaruh para pihak dapat menimbulkan, antara lain: ketidakjelasan hak kepemilikan, keragaman pengguna, memonopoli terhadap kawasan hutan, perebutan hasil dan konflik. Perbedaan luas penguasaan kawasan hutan yang menimbulkan rasa ketidakadilan juga diakibatkan kurangnya kontrol negara dalam kepemilikan lahan dan pembagian hasil (Shivakoti dan Ostrom, 2007). Rumusan masalah tersebut menjadi landasan pentingnya penelitian dilakukan. Analisis perubahan akses dalam penelitian dilakukan dengan tiga tahapan yaitu: 1) Identifikasi akses serta penyebab, 2) Bentuk akses, 3) Hak kepemilikan, dan 4) Legalitas dan status pengguna.

\section{METODE PENELITIAN}

Penelitian ini dilakukan di KPHP Meranti di Kabupaten Musi Banyuasin Provinsi Sumatera Selatan pada bulan September 2015 sampai dengan Juni 2016. Metode penelitian menggunakan pendekatan kualitatif dengan teknik pengumpulan data menggunakan analisis spasial, studi peta dan studi literatur, langkah kerja dengan pendekatan Rapid Land Tenure Assessment (RaTA) (Galudra et al., 2010). Pengumpulan data meliputi perubahan lahan, studi dokumen, sejarah dan peta perubahan. Mengetahui bentuk akses, peran dan status pengguna dilakukan dengan in-depth interview secara snowball sampling sebanyak 123 orang nara sumber kunci terdiri dari 97 orang masyarakat dari delapan desa, empat orang dari Kementerian Lingkungan 
Hidup dan Kehutanan (KLHK), delapan orang dari Dinas Kehutanan Kabupaten, empat orang dari Dinas Kehutanan Provinsi dan lima orang unit pelaksana teknis (UPT) KLHK dan lima orang pemegang izin usaha bidang kehutanan. Hasil penelitian menjelaskan bagaimana akses terjadi, akibat yang ditimbulkan. Parameter analisis akses adalah bentuk akses, legalitas akses, kepentingan dan aturan yang mengatur pengguna.

\section{HASIL DAN PEMBAHASAN}

\section{A. Identifikasi Penyebab Akses}

Identifikasi penyebab timbulnya akses diurai dari faktor yang memengaruhi,, antara lain; 1) Perubahan luas kawasan hutan, 2) Kendala lapangan dan proses birokrasi dalam tata batas, dan 3) Kendala kegiatan pengawasan dan pemeliharaan batas kawasan.

1. Perubahan luas kawasan hutan

Perubahan pengelolaan atau pengguna diikuti dengan perubahan luas area kelola, serta aturan hukum yang mengatur. Perubahan pengelolaan sudah terjadi sejak era-kolonial Belanda hingga Rencana Tata Ruang Wilayah Provinsi (RTRWP) Sumatera Selatan Tahun 2014. Era-kolonial Belanda, kawasan hutan dibuat plot sebanyak 52 plot yang disebut dengan "register". Register yang berada dan berdekatan dengan wilayah kerja Kesatuan Pengelolaan Hutan Produksi (KPHP) Meranti adalah : 1) Register-2 Grensregelingskaart Soko-soeban dengan Governments Besluit van 30 Juli 1924 Nomor 1, 2) Register-3 Grensregeling-skaart Boering dengan Government Besluit van 30 Juli 1924 Nomor 2 seluas 582 hektar, 3) Register-4 Grensregelingskaart Semandai dengan Government Besluit tanggal 30 Juli 1924 Nomor 2 seluas 1.806 hektar, dan 4) Register-37 Grensregelingskaart Dangkoe dengan Governments Besluit van 30 Juli 1924 Nomor 37 atau saat ini dikenal dengan Suaka Alam Dangku seluas \pm 31.752 hektar. Dinamika perubahan penataan kembali kawasan hutan dilakukan sejak adanya Tata Guna Hutan Kesepakatan (TGHK) Tahun 1982 sampai adanya usulan pelepasan kawasan karena adanya Dampak Penting dan Cukup Luas serta bernilai Strategis (DPCLS) tahun 2014 seluas \pm 19.645 hektar. Kondisi ini mengakibatkan Kementerian Kehutanan melakukan enclave pada kawasan hutan melalui Surat Keputusan Menteri Kehutanan (SK Menhut) Nomor 866/Menhut-II/2014. Dinamika perubahan luas kawasan hutan sebagaimana terlihat pada Tabel 1 .

Tabel 1. Dinamika pengelolaan kawasan hutan di Provisi Sumatera Selatan

Table 1. Dynamics of forest regime in South Sumatra Province

\begin{tabular}{|c|c|c|c|}
\hline $\begin{array}{l}\text { Perubahan pengelolaan } \\
\text { (Change of forest regime) }\end{array}$ & $\begin{array}{l}\text { Dasar hukum } \\
\text { (Basic of law) }\end{array}$ & $\begin{array}{l}\text { Institusi penguasa } \\
\text { (Institution of arbiter) }\end{array}$ & $\begin{array}{l}\text { Luas/hektar } \\
\text { (Area/hectare) }\end{array}$ \\
\hline Register & Governments Besluit van & Kolonial & 1.073 .679 \\
\hline TGHK & $\begin{array}{l}1834 / 1924 *) \\
\text { SK Menteri Pertanian Nomor } 925 /\end{array}$ & Kementerian Pertanian & 4.624 .950 \\
\hline Peta Perubahan & $\begin{array}{l}\text { Kpts/Um/12/1982*) } \\
\text { SK Menteri Kehutanan Nomor } 410 /\end{array}$ & Departemen Kehutanan & 5.214 .600 \\
\hline RTRWP 1992 & $\begin{array}{l}\text { Kpts-II/1986*) } \\
\text { SK Menteri Kehutanan }\end{array}$ & Departemen Kehutanan & 4.416 .837 \\
\hline RTRWP 2007 & $\begin{array}{l}\text { Nomor 76/Kpts-II/2001*) } \\
\text { Keputusan Menteri Kehutanan }\end{array}$ & Kementerian Kehutanan & 4.247 .469 \\
\hline DPCLS & $\begin{array}{l}\text { Nomor SK.822/Menhut-II/2013*) } \\
\text { Keputusan Menteri Kehutanan } \\
\text { Nomor SK.866/Menhut-II/2014*) }\end{array}$ & Kementerian Kehutanan & 3.466 .901 \\
\hline
\end{tabular}

Sumber (Source): Data primer, diolah (Primary data, prcessed) 
2. Kendala proses tata batas kawasan

Dinamika perubahan pengelolaan terkait tata batas menimbulkan berbagai permasalahan dalam proses tata batas. Permasalahan teknis perubahan dapat mengakibatkan ketidakjelasan batas kawasan akibat tumpang tindih (overlapping). Selain itu secara psikologis menurukan semangat dan etos kinerja juru ukur atau operator lapangan akibat tidak selesai-selesainya pekerjaan. Selain kedua permasalahan diatas, kendala tata batas lainnya adalah, inkonsistensi terhadap aturan dalam tahapan tahapan dalam proses pengukuhan batas kawasan hutan. Pasal 14 dan Pasal 15 UU Nomor 41 Tahun 1999, menjelaskan bahwa proses dimulai dari, yaitu a) penunjukan kawasan hutan, b) penataan batas kawasan hutan, c) pemetaan kawasan hutan, dan d) penetapan kawasan hutan. Inkonsistensi muncul dari sejak diterbitkannya SK Menhut Nomor 76/ KPTS-II/2001 jo. SK Menhut Nomor SK. 822/Menhut-II/2013, dan SK Menhut Nomor SK.866/Menhut-II/2014 tentang Penunjukan Kawasan Hutan dan Perairan Provinsi Sumatera Selatan. Keputusan tersebut secara legal formal berdampak pada batalnya Keputusan Penetapan secara parsial-parsial pada Tahun 1998, akibat kembali kepada keputusan penunjukan kawasan hutan seProvinsi Sumatera Selatan. Yang dikuatkan dengan amar putusan Mahkamah Konstitusi Nomor 35/PUU-X/2012 terkait judicial review definisi kawasan hutan dari UU Nomor 41 Tahun 1999, yaitu: kawasan hutan baru dapat disebut kawasan hutan apabila telah ada "keputusan penetapan" bukan hanya "keputusan penunjukan", sehingga keputusan penunjukan hanya bersifat pengaturan kawasan secara administratif bukan legalitas..

Kendala tata batas selanjutnya lamanya proses, dari tahapan penunjukan hingga penetapan. Tidak jarang pada akhir tahapan yaitu penetapan menjadi permasalahan baru. Ketika keputusan penetapan dikeluarkan, kenyataan lapangan batas kawasan hutan telah berubah dan ditempati pengguna baru (Sinabutar, Nugroho, Kartodihardjo \& Darusman 2015; Sylviani dan Hakim, 2014).

Sejarah pelaksanaan tata batas kawasan hutan di Kabupaten Musi Banyuasin dimulai tahun anggaran 1990/1991 dan 1994/1995 dan selesai secara bertahap pada tahun anggaran 1995/1996 dan1997/1998. Berita Acara Tata Batas (BATB) dilaksanakan pada tahun 1996 dan 1997 dan sebahagian telah memiliki keputusan penetapan. Wilayah KPHP Meranti memiliki BATB pada tanggal 16 Oktober 2001 dan Keputusan Penetapan Nomor: $\quad$ SK.3595/Menhut-VII/KUH/2014 tanggal 2 Mei 2014, yang berarti 13 tahun setelah BATB, baru memiliki kekuatan hukum tetap. Walaupun keputusan penetapan tersebut hanya sebahagian dari kelompok hutan produksi Meranti atau sebahagian dari wilayah KPHP Meranti, akibat tata batas kawasan belum temu-gelang. Hasil studi dokumen menunjukan tidak selesainya tata batas hingga temu-gelang di Hutan Produksi (HP) Meranti disebabkan, antara lain: a) pengaruh bertambah-berkurangnya izin dan perubahan luas areal konsesi, b) prosedur birokrasi yang berbelit-belit, dan c) terbatasnya anggaran pelaksanaan tata batas.

Hasil pengamatan lapangan memperlihatkan bahwa kondisi saat ini tanda batas hanya dipahami sebatas garis-garis dan titik titik koordinat diatas kertas peta. Pal batas secara fisik lapangannya bisa jadi sudah berpindah atau sudah tidak ada. Batas yang dibuat masyarakat secara alami berupa tanaman karet, pisang atau tanaman pagar lebih kuat dan mudah terlihat dan dipahami. Perkembangan tata batas di Kabupaten Musi Banyuasin, sebagaimana terlihat pada Tabel 2 .

3. Kendala pengawasan dan pemeliharaan

Pengawasan dan pemeliharaan batas kawasan merupakan proses kegiatan dalam perlindungan kawasan hutan. Keberhasilan pengawasan hutan dapat dilihat dari semakin kecilnya dampak (low impact) kerusakan yang ditimbulkan. Pengawasan kawasan hutan 
Tabel 2 Perkembangan tata batas kawasan hutan Kabupaten Musi Banyuasin Table 2 Forest Area boundaries progres in Musi Banyuasin Regency

\begin{tabular}{|c|c|c|c|c|c|}
\hline $\begin{array}{l}\text { Kelompok Hutan } \\
\text { (Forest groups) }\end{array}$ & $\begin{array}{c}\text { Waktu } \\
\text { Pelaksanaan/ } \\
\text { Tahun } \\
\text { (Accessof time } \\
\text { /years) }\end{array}$ & $\begin{array}{c}\text { Luas/ } \\
\text { Hektar } \\
\text { (Area/ } \\
\text { Hectare) }\end{array}$ & $\begin{array}{c}\text { Berita Acara Tata } \\
\text { Batas } \\
\text { (Boundaries } \\
\text { official report) }\end{array}$ & $\begin{array}{c}\text { Tanggal } \\
\text { Pengesahan } \\
\text { (Authentication } \\
\text { Date) }\end{array}$ & $\begin{array}{c}\text { Keputusan } \\
\text { Penetapan } \\
\text { (Forestry Minister } \\
\text { Decree) }\end{array}$ \\
\hline SM. Dangku & $1985 / 86$ & 31.752 & $24-3-1986$ & $18-01-91$ & 245/Kpts-II/1991 \\
\hline Dangku & $1995 / 96$ & - & $12-12-1995$ & - & 245/Kpts-II/1991 \\
\hline Air Lalan I & $1987 / 88$ & - & 21-09-1987 & $18-01-91$ & SK.3093/Menhut-VII/KUH/2014 \\
\hline Air Lalan II & $1988 / 89$ & - & 20-02-1989 & $18-01-91$ & SK.3093/Menhut-VII/KUH/2014 \\
\hline S. Sembulan & $1989 / 90$ & - & - & - & 110/Kpts-II/1999 03/03/1999 \\
\hline Meranti I,II & $1990 / 91$ & - & - & - & 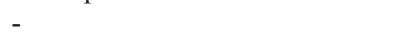 \\
\hline Meranti I & $1994 / 95$ & - & - & - & SK.3595/Menhut-VII/KUH/2014 \\
\hline Mangsang Mendis & $1993 / 94$ & - & - & - & SK.3093/Menhut-VII/KUH/2014 \\
\hline Telang I, II & $1993 / 94$ & 1.237 & 31-03-1994 & $11-11-97$ & SK.3577/Menhut-VII/KUH/2014 \\
\hline Upang I, II & $1993 / 94$ & 649 & 31-03-1994 & $10-02-98$ & 72/Kpts-II/1997 \\
\hline Lalan T Dalam & $1995 / 96$ & - & 24-01-1996 & - & - \\
\hline Lalan T Dalam & $1994 / 96$ & 26.069 & $19-12-2000$ & - & Tidak ada keterangan*) \\
\hline Muara Saleh & $1995 / 96$ & - & $21-12-1995$ & $11-11-97$ & 3596/Menhut-VII/KUH/2014 \\
\hline P.Alang G. & $1985 / 86$ & 16,78 & $12-03-1996$ & $10-02-98$ & 81/Kpts-II/1998 \\
\hline Meranti I & $1995 / 96$ & - & 24-01-1996 & $16-10-01$ & SK.3595/Menhut-VII/KUH/2014 \\
\hline Meranti II & $1996 / 97$ & - & 27-08-1997 & - & - \\
\hline A.Lalan I & $1995 / 96$ & - & 24-01-1996 & $16-10-01$ & SK.3093/Menhut-VII/KUH/2014 \\
\hline A.Lalan II & $1996 / 97$ & - & 26-09-1997 & - & SK.3093/Menhut-VII/KUH/2014 \\
\hline
\end{tabular}

*) Apakah menyatu dengan SK Air Lalan

Sumber (source) : http://webgis.dephut.go.id:8080/kemenhut/images/peta-cetak/Penetapan_KH /PetaTAP_

Sumatera.pdf

sangat terkait dengan tanda batas yang akan diperiksa/diawasi. Pengaruh kepentingan dan integritas serta kemampuan sumber daya manusia (SDM) sangat erat terkait pengaruh pengawasan (Nurtjahjawilasa, Kartodihardjo, Nurrochmat \& Justianto, 2015). Pengawasan kawasan hutan diatur dalam Peraturan Menteri Kehutanan (Permenhut) Nomor P.43/MenhutII/2013 dengan kegiatan, antara lain; 1) melaksanakan pemeliharaan dan pengamanan batas areal kerja, 2) melakukan rintis batas dan pal batas sebagai acuan letak batas areal kerja, 3) menyampaikan laporan hasil pelaksanaan pemeliharaan dan pengamanan batas areal per tahun kepada kantor Balai Pemantauan Kawasan Hutan (BPKH), 4) pelaksanaan orientasi dan rekonstruksi batas areal kerja, serta 5) orientasi dan rekonstruksi batas dilakukan oleh pemegang izin pemanfaatan hutan, pemegang izin pinjam pakai kawasan hutan dengan pengawasan BPKH.
Hasil penelitian menunjukkan kendala pengawasan dan pemeliharaan tata batas karena, yaitu: a) permasalahan ketersediaan anggaran, b) keseriusan operator lapangan dan c) kurangnya jumlah Polisi Kehutanan (Polhut) sebagai penegak hukum dan pelaksana patroli lapangan. Lemahnya pengawasan juga memunculkan motif pengguna baru. Akses masyarakat terjadi akibat adanya pengaruh dari: a) semakin terbukanya aksesibilitas ke kawasan hutan dan b) kemudahan kredit untuk memiliki kendaraan bermotor. Dampak lemahnya pengawasan kawasan hutan di Kabupaten Musi Banyuasin, yaitu: a) terdapat 18 pemilik izin usaha (perkebunan) yang masuk ke dalam kawasan hutan, namun memiliki izin usaha perkebunan dari pemerintah daerah atau izin tidak prosedural; b) pemilik perkebunan membeli lahan partikelir yang memiliki izin pada era kolonial Eigendom (milik mutlak) 
dan Verponding (harta tetap) di dalam kawasan hutan; c) pemilik usaha dengan sengaja merambah kawasan hutan; dan d) pal batas banyak hilang yang dicabut dari titiknya dan atau dipindah.

Akses struktur lain dari lemahnya pengawasan ialah munculnya desa transmigrasi swakarsa mandiri, yang merupakan desa transmigrasi bentuk "samaran program transmigrasi pemerintah". Dibentuk oleh masyarakat pendatang umumnya dari Provinsi Lampung membuat nama dan struktur desa baru, namun tidak memiliki izin pemerintah daerah. Akses transmigrasi ilegal yang dilakukan pendatang difasilitasi tokoh masyarakat dan oknum lembaga swadaya masyarakat (LSM) lokal. Para pelaku menjual lahan rata-rata Rp2.000.000-Rp5.000.000 per hektar.

\section{B. Perubahan Mekanisme Akses}

1. Perubahan akses mekanisme hak

Tantangan pengelolaan sumber daya adalah: a) lemahnya kontrol karena adanya kepentingan pengguna dengan mengubah bentuk akses untuk keuntungan individu, dan b) perangkat hukum dan aturan tidak mudah dipahami dan dilaksanakan dengan baik dan c) penghayatan pengelolaan pada kepedulian lingkungan hanya sebatas melaksakan tugas dan hubugan birokrasi. Perubahan akses mekanisme hak, umumnya selalu diikuti dengan pemberian istilah baru bagi pengguna, sebagai contoh: Izin Usaha Pemanfaatan Hasil Hutan Kayu Hutan Alam (IUPHHK-HA) sebelumnya Hak Pengusahaan Hutan (HPH), Izin Usaha Pemanfaatan Hasil Hutan Kayu Hutan Tanaman (IUPHHK-HT) sebelumnya Hak Pengusahaan Hutan Tanaman Industri (HPHTI), Izin Pinjam Pakai Kawasan Hutan (IPPKH), Hutan Tanaman Rakyat (HTR), Hutan Desa (HD), Hutan Kemasyarakatan (HKm) dan Hutan Adat. Perubahan nama atau istilah akan memunculkan perhatian dan pemahaman baru sebagaimana dijelaskan Hendricks (1991) berawal klaim terjadi dari adanya proses pemberian nama pada objek yang tidak dikenal. Pemberian nama yang tidak dikenal memancing perhatian, ketegangan dan mencari keuntungan oleh para pihak, perbedaan pemahaman, kepentingan.

Perubahan aturan dari relasi kekuasaan erat kaitannya dalam menentukan pengguna baru dan tidak jarang disertai dengan pemberian istilah baru dan menimbulkan bentuk akses baru. Akses baru akan menguntungkan pihak pengguna baru sementara pengguna sebelumnya menjadi ilegal. Perubahan akses mekanisme hak, sejak 1969-2015 sebagaimana terlihat pada Tabel 3 .

Perubahan aturan pemanfaatan, secara garis besar terbagi ke dalam 4 tahap perubahan, yaitu;

a) UU Nomor 78 Tahun 1958 Tentang Penanaman Modal Asing. Kebijakan ekonomi pemerintah bertujuan untuk meningkatkan pendapatan negara sebagai modal pembangunan dengan menarik investor asing. Mekanisme akses dari aturan tersebut pemberian izin pengusahaan hutan yaitu: Padeca Co. Ltd (Korea) dan Sunrise Co. Ltd (Korea);

b) UU Nomor 6 Tahun 1968 Tentang Penanaman Modal Dalam Negeri (PMDN), perubahan kepemilikan modal investasi Hak Penguasaan Hutan (HPH) dan Hak Pemungutan Hasil Hutan (HPHH) dari swasta asing ke swasta nasional. Perubahan akses dari kebijakan tersebut adalah perusahaan Padeca Co. Ltd terbagi menjadi 3 badan hukum perusahaan swasta nasional, yaitu: PT. Padeca, PT. Wisma Lukita, dan PT. Niti Remaja;

c) PP Nomor 10 Tahun 1995 Tentang Tim Terpadu Pengamanan Hutan (TTPH) dan terkait penilaian kinerja $\mathrm{HPH}$ pada tahun 1995/96 menjadi dasar pencabutan izin HPH. Pasca pencabutan HPH memunculkan akses baru yaitu izin konsesi Hutan Tanaman Industri (HTI) PT. Musi Hutan Persada dan PT. 
Tabel 3. Perubahan rezim pada akses mekanisme hak

Table 3. Change of regime on rights-based access

\begin{tabular}{|c|c|c|c|}
\hline $\begin{array}{c}\text { Akses } \\
(\text { Access })\end{array}$ & $\begin{array}{l}\text { Hasil/Manfaat } \\
\text { (Result/Benefit) }\end{array}$ & $\begin{array}{l}\text { Aliran kepentingan } \\
\text { (The flow of interest) }\end{array}$ & $\begin{array}{c}\text { Cara perubahan akses } \\
\text { (The way of access changed) }\end{array}$ \\
\hline $\begin{array}{l}\text { Perusahaan HPH } \\
(1969 / 70- \\
1993 / 98)\end{array}$ & Produksi kayu & $\begin{array}{l}\text { Memengaruhi kebijakan } \\
\text { untuk mempertahankan } \\
\text { areal konsesi HPH }\end{array}$ & $\begin{array}{l}\text { Aturan: pelaksanan Sistem Silvikultur } \\
\text { Intensif (SILIN), pencegahan pencurian } \\
\text { kayu dengan tim pengamanan hutan } \\
\text { terpadu, pembatasan kuota tebang. }\end{array}$ \\
\hline $\begin{array}{l}\text { Perusahaan HTI } \\
(1990-2015)\end{array}$ & $\begin{array}{l}\text { Produksi kayu } \\
\text { HTI }\end{array}$ & $\begin{array}{l}\text { Mengatasi perambahan } \\
\text { hutan oleh masyarakat dan } \\
\text { pengendalian kebakaran } \\
\text { hutan }\end{array}$ & $\begin{array}{l}\text { Penggunaan Dana Reboisasi (DR), } \\
\text { percepatan pembangunan HTI dengan } \\
\text { fasilitasi sarana-prasarana, program } \\
\text { pemberantasan illegal loging. }\end{array}$ \\
\hline $\begin{array}{l}\text { Izin Pinjam Pakai } \\
\text { Kawasan-IPHHK } \\
(1985 / 2008-2015)\end{array}$ & $\begin{array}{l}\text { Pertambangan } \\
\text { mineral dan } \\
\text { minyak gas }\end{array}$ & $\begin{array}{l}\text { Pertambangan dapat } \\
\text { dilaksanakan di dalam } \\
\text { kawasan hutan areal HTI. }\end{array}$ & $\begin{array}{l}\text { Peraturan pertambangan tertutup dan } \\
\text { terbuka, fasilitasi pengamanan areal } \\
\text { pertambangan. }\end{array}$ \\
\hline $\begin{array}{l}\text { Hutan Tanaman } \\
\text { Rakyat (HTR) } \\
(2013-2015)\end{array}$ & $\begin{array}{l}\text { Kawasan } \\
\text { hutan produksi } \\
\text { dikelola } \\
\text { masyarakat }\end{array}$ & $\begin{array}{l}\text { Memeroleh kawasan } \\
\text { hutan untuk dikelola } \\
\text { selama } 30 \text { tahun dan dapat } \\
\text { diperpanjang. }\end{array}$ & $\begin{array}{l}\text { Kelompok masyarakat desa sekitar } \\
\text { dengan pola kemitraan atau developer } \\
\text { dengan peran pihak ketiga. }\end{array}$ \\
\hline $\begin{array}{l}\text { Inventrarisasi } \\
\text { Penguasaan, } \\
\text { Pemilikan, } \\
\text { Penggunaan, } \\
\text { Pemanfaatan } \\
\text { Tanah (IP4T) } \\
(2014-2015)\end{array}$ & $\begin{array}{l}\text { Ekonomi } \\
\text { individu, } \\
\text { pekerjaan }\end{array}$ & $\begin{array}{l}\text { Pelepasan kawasan } \\
\text { hutan menjadi hak milik } \\
\text { masyarakat, pemberian } \\
\text { bantuan usaha masyarakat }\end{array}$ & $\begin{array}{l}\text { Penguatan kapasitas sosial dengan } \\
\text { pengembalian hutan adat/ulayat dengan } \\
\text { dilakukannya proyek Inventrarisasi } \\
\text { Penguasaan, Pemilikan Penggunaan } \\
\text { dan Pemanfaatan Tanah (IP4T) di } \\
\text { kawasan hutan. }\end{array}$ \\
\hline
\end{tabular}

Sumber (Source) : Diolah dari data lapangan, 2015, dan modifikasi dari Priyatna et al., 2013 (Processed from field collecting, 2015, and modified from Priyatna et al., 2013)

Pakerin berdasarkan Keputusan Menteri Kehutanan (Kepmenhut) Nomor 126/ KPTS-II/1990 dan 226/KPTS-II/1998;

d) UU Nomor 41 Tahun 1999 dan turunannya terkait: 1) tindak lanjut percepatan pembangunan HTI (enam unit konsesi HTI sejak 2004-2009; 2) pembangunan Hutan Tanaman Rakyat (HTR); 3) Izin Pinjam Pakai Kawasan Hutan (IPPKH); dan 4) pengelolaan wilayah KPHP.

Perubahan izin sebagaimana terlihat pada Tabel 4. Peta perubahan pengguna kawasan pada HP Meranti sebagaimana Gambar 1.

\section{Perubahan akses mekanisme struktur}

Akses mekanisme struktur pada HP Meranti sangat terkait dengan sejarah pembukaan hutan era-HPH. Suku asli di wilayah HP
Meranti adalah suku Musi dan suku Kubu. Selain kedua suku tersebut, pendatang yang dominan adalah suku Komering yang hijrah dalam dua gelombang; pertama pelarian dari tentara pemberontakan Pemerintahan Revolusioner Republik Indonesia (PRRI) tahun 1957-1959, dan kedua pencari kayu era "banjir log" (eksploitasi kayu besar-besaran) yang merupakan pendatang dari Desa Sei Lapan. Ketiga suku tersebut merupakan suku yang lebih dominan dalam membentuk akses mekanisme struktur.

Berdasarkan akses mekanisme struktur dari ketiga suku dominan tersebut, penguasaan lahan dapat digolongkan dalam 5 (lima) bentuk akses struktur, yaitu: 1) Suku Kubu/ Suku Anak Dalam (SAD), sebagai penduduk asli. Akses mekanisme struktur yang 
Tabel 4 Izin bidang kehutanan dari akses mekanisme hak pasca UU Nomor 41 Tahun 1999 Table 4 Permit of forestry sector from rights-based access after Law of 41/1999

\begin{tabular}{|c|c|c|c|c|}
\hline No & $\begin{array}{c}\text { Mekanisme hak } \\
\text { (Rights-based access) }\end{array}$ & $\begin{array}{l}\text { Keputusan Menteri } \\
\text { (Minister decree) }\end{array}$ & $\begin{array}{l}\text { Lama waktu/tahun } \\
\text { (Duration/year) }\end{array}$ & $\begin{array}{c}\text { Luas/hektar } \\
\text { (Area/hectare) }\end{array}$ \\
\hline 1 & PT. REKI (Sumsel) & SK.293/Menhut-I1/2007*) & 100 & 52.170 \\
\hline 2 & PT. BPP - I & 337/Menhut-II/2004*) & 100 & 59.345 \\
\hline 3 & PT. BPP - II & SK.79/Kpts-II/2009*) & 60 & 24.050 \\
\hline 4 & PT. RHM & SK.90/Menhut-II/2007*) & 60 & 67.100 \\
\hline 5 & PT. SBB & 249/ Menhut-II/2009*) & 60 & 55.055 \\
\hline 6 & PT. WAM & SK./Menhut-II/2009*) & 30 & 6.290 \\
\hline 7 & Eks PT. Pakerin & 226/Kpts-II/1998*) & 60 & 43.380 \\
\hline 8 & PT. Samhutani & 86/Kpts-II/1999*) & 30 & 58,88 \\
\hline 9 & Wilayah Tertentu & 689/Menhut-II/2012*) & - & 35,41 \\
\hline
\end{tabular}

Sumber (Source): Data primer, diolah (Primary data, prcessed)

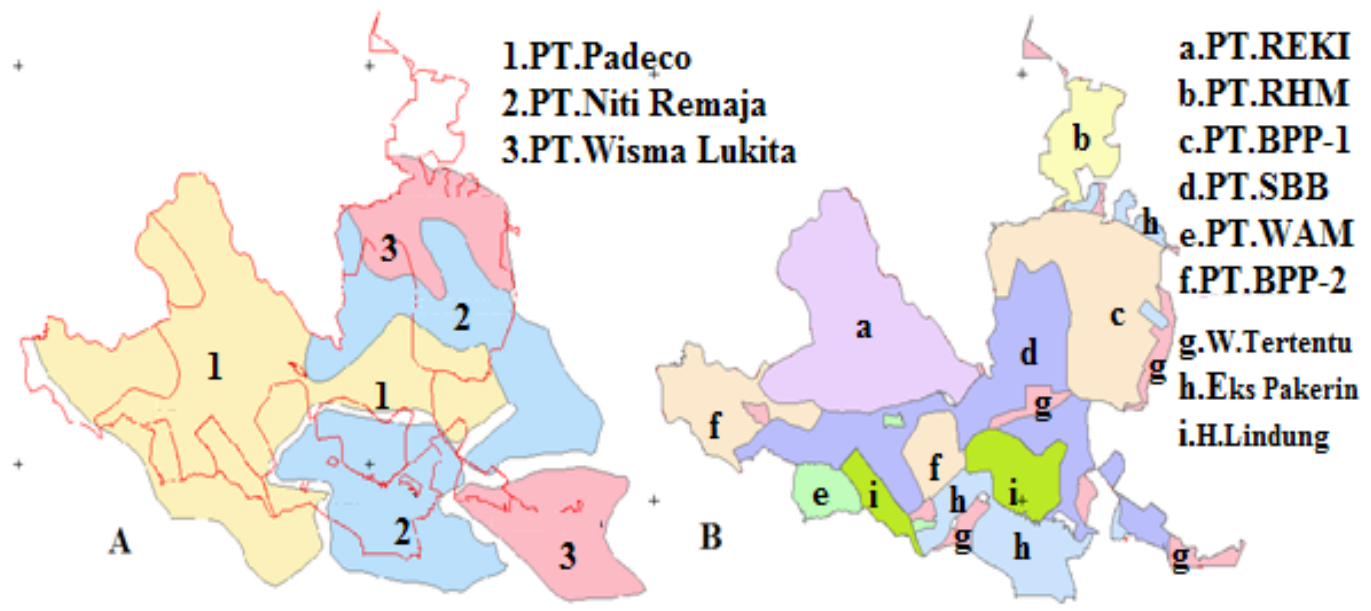

A. Sumber (Source): Lampiran Peta didalam Laporan Pembangunan Kehutanan Sumatera Selatan, 1985 (Map attachment in Forest Development Report South Sumatra 1985)

B. Sumber (Source) Lampiran Peta Surat Keputusan Menteri Kehutanan*) (Map attachment in Minister Decree*)

Gambar 1 Perubahan akses mekanisme hak (A) 1969-1993/1998 dan (B) 1998 s/d saat ini Figure 1. Change of rights-base mechanism access (A) 1969-1993/1998 and (B) 1998 to date

digunakan adalah klaim hutan merupakan tempat tinggal dan wilayah jelajah dalam mencari kebutuhan hidupnya (homering) sebagai pemilik sah terhadap kawasan hutan; 2) Sistem perladangan berpindah, umumnya dilakukan oleh suku Musi. Perladangan berpindah dilakukan masyarakat dengan membuka hutan untuk budidaya tanaman musiman (padi, jahe, ubi, dan palawija lainnya). Area bekas perladangan berpindah, diklaim masyarakat sebagai hak milik; 3) Para rimbo, umumnya dilakukan oleh Suku Musi dan Suku Komering. Para rimbo merupakan kebun karet hutan milik masyarakat yang ditanam secara tradisional dan keberadaan karet di hutan menunjukan kepemilikan tanah milik masyarakat; 4) Perkebunan Inti Rakyat (PIR), umumnya dilakukan suku pendatang. PIR berawal dari perkebunan sawit milik rakyat yang difasilitasi perusahaan sawit. 
Namun selanjutnya, PIR berkembang menjadi alat untuk mengakses lahan; 5) Pendatang Lampung, merupakan pendatang yang umumnya orang Jawa berasal dari Provinsi Lampung yang difasilitasi oknum tokoh masyarakat. Motif mendapatkan keuntungan pribadi dari jual-beli lahan dalam kawasan hutan. Akses mekanisme struktur menjadi polemik, jika tidak diselesaikan secara bijaksana dapat memicu terjadinya konflik terbuka dengan pemegang izin usaha (Gamin, Nugroho \& Kartodihardjo, 2014).

Strategi akses dan memertahankan lahan dari mekanisme struktur oleh masyarakat dilakukan dengan cara, antara lain: a) mengubah biofisik kawasan hutan milik perusahaan menjadi kebun sawit dan atau karet, b) melakukan aksi demonstrasi, c) pemancangan papan atas nama pemilik, d) mengganggu aktivitas perusahaan, dan e) melakukan pendekatan terhadap legislatif yaitu Dewan Perwakilan Rakyat Daerah (DPRD) lewat partai politik. Bentuk akses berdasarkan mekanisme struktur pada wilayah KPHP Meranti dijelaskan pada Tabel 5.

\section{Hak Kepemilikan Pengguna}

Perubahan akses terhadap kawasan hutan yang sangat cepat, mengakibatkan ketidakjelasan pemilik dan keragaman pengguna. Berdasarkan norma dan hukum di masyarakat, penggunaan hanya pengakuan dari tokoh masyarakat dan sebagian ada yang tertulis berupa Surat Keterangan Tanah (SKT) yang diterbitkan oknum kepala desa. SKT di dalam PP Nomor 24 Tahun 1997, dapat dikategorikan sebagai alat bukti yang sah untuk diajukan dalam pendaftaran tanah jika diketahui oleh camat. Permasalahan di lapangan adalah seluruh SKT hanya diketahui

Tabel 5. Tipe pelaku dan strategi akses mekanisme struktur

Table 5. Agent and strategies of access structure mechanism

\begin{tabular}{|c|c|c|c|}
\hline $\begin{array}{l}\text { Tipe Pelaku } \\
\text { (Agent) }\end{array}$ & $\begin{array}{c}\text { Strategi akses } \\
(\text { Access strategy) }\end{array}$ & $\begin{array}{l}\text { Strategi memertahankan lahan } \\
\text { (Strategy of land defence) }\end{array}$ & $\begin{array}{c}\text { Modal akses } \\
\text { (Modal of access) }\end{array}$ \\
\hline $\begin{array}{l}\text { Suku Anak } \\
\text { Dalam/SAD }\end{array}$ & $\begin{array}{l}\text { Klaim lahan dominasi hak } \\
\text { pemilik hutan yang sah } \\
\text { masyarakat asli setempat yaitu } \\
\text { Suku Kubu. }\end{array}$ & $\begin{array}{l}\text { Membuat patok (tanda batas) dan } \\
\text { papan pengumuman milik SAD dan } \\
\text { merusak tanaman milik HTI dan } \\
\text { perkebunan. }\end{array}$ & $\begin{array}{l}\text { Identitas dan relasi } \\
\text { sosial, adat lokal } \\
\text { (homering). }\end{array}$ \\
\hline $\begin{array}{l}\text { Perladangan } \\
\text { berpindah }\end{array}$ & $\begin{array}{l}\text { Membuka dan atau membakar } \\
\text { lahan kawasan yang masih } \\
\text { berhutan atau HTI/perkebunan }\end{array}$ & $\begin{array}{l}\text { Menanam tanaman karet atau pisang } \\
\text { sebagai simbol kepemilikan dan } \\
\text { pagar batas kebun. }\end{array}$ & $\begin{array}{l}\text { Modal identitas } \\
\text { sosial, otoritas dan } \\
\text { relasi sosial }\end{array}$ \\
\hline $\begin{array}{l}\text { Partuanan } \\
\text { para rimbo }\end{array}$ & $\begin{array}{llr}\text { Pengakuan } & \text { bahwa tanaman } \\
\text { karet hutan merupakan milik } \\
\text { masyarakat pembagian dari } \\
\text { pesirah (para rimbo). }\end{array}$ & $\begin{array}{l}\text { Memberi nama pada setiap batas } \\
\text { pohon karet, sebagai tanda pemilik } \\
\text { lahan; Contoh: para hilir, para ulu. }\end{array}$ & $\begin{array}{l}\text { Modal relasi sosial } \\
\text { dalam hubungan } \\
\text { patron-klein }\end{array}$ \\
\hline $\begin{array}{l}\text { Perkebunan } \\
\text { inti rakyat } \\
(\mathrm{PIR})\end{array}$ & $\begin{array}{l}\text { Membeli lahan dari tokoh } \\
\text { masyarakat yang berdekat } \\
\text { perkebunan di kawasan hutan } \\
\text { dan membentuk kelompok PIR }\end{array}$ & $\begin{array}{l}\text { Membuat akte notaris dan bukti } \\
\text { kepemilikan yang diketahui camat } \\
\text { dan lurah setempat, menanam jenis } \\
\text { yang sama dengan milik perkebunan }\end{array}$ & Modal finansial \\
\hline $\begin{array}{l}\text { Pendatang } \\
\text { Lampung }\end{array}$ & $\begin{array}{l}\text { Didatangkan orang dari Provinsi } \\
\text { Lampung pada saat pemilihan } \\
\text { kepala daerah, atau jual-beli } \\
\text { lahan dari oknum kepala desa } \\
\text { dengan pemberian Surat } \\
\text { Keterangan Tanah (SKT) }\end{array}$ & $\begin{array}{l}\text { Menanam tanaman semusim (ubi } \\
\text { kayu dan jagung), membangun } \\
\text { rumah tinggal untuk menunjukan } \\
\text { sebagai penduduk setempat, } \\
\text { membuat nama dan struktur } \\
\text { organisasi desa }\end{array}$ & Modal finansial \\
\hline
\end{tabular}

Sumber (Source) : Diolah dari data lapangan, 2015, dan modifikasi dari Priyatna et al., 2013 (Processed from field collecting, 2015, and modified from Priyatna et al., 2013) 
kepala desa. Oleh karena itu, syarat untuk mengusulkan kawasan hutan agar di enclave menjadi tidak dapat diproses (tidak sah) ketika akan merevisi Rencana Tata Ruang Wilayah Provinsi (RTRWP). Bagi masyarakat yang hanya memiliki SKT sebagai bukti kepemilikan tanah untuk pengajuan revisi RTRWP, pada saat ditolak mengakibatkan terjadinya konflik (Gamin et al., 2014).

Terdapat kesamaan arti antara lahan budidaya dan kawasan hutan di masyarakat, sehingga ketika hutan dalam keadaan akses terbuka (open access), maka persepsi masyarakat bukanlah kawasan hutan sehingga dapat dikelola atau diperjual-belikan. Lahan hasil jual-beli antar anggota masyarakat terdapat pada hampir seluruh wilayah KPHP Meranti. Klaim lahan yang berbeda-beda mengakibatkan status pengguna kawasan hutan menjadi beragam, antara lain: a) pemilik kebun sawit/karet/kebun campuran, b) pengguna kawasan tidak resmi usaha perkebunan skala besar, c) pengguna resmi yang memiliki bukti tertulis dari Bupati namun tidak melalui prosedur yang berlaku, d) masyarakat klaim hutan adat, dan e) penyewa lahan. Keragaman pengguna mengakibatkan tumpang tindih pemanfaatan. Tumpang tindih penggunaan di KPHP Meranti disajikan sebagaimana Tabel 6 dan Tabel 7.

Tabel 6 dan Tabel 7 memerlihatkan tumpang-tindih antara pemukiman, kebun milik masyarakat, izin Hutan Tanaman Industri (HTI) dan Izin Pinjam Pakai Kawasan Hutan (IPPKH) dan wilayah tertentu kelola KPHP Meranti. Sebanyak 22 unit IPPKH dan 4 unit izin perkebunan nonprosedural tumpang tindih dengan HTI dan di dalamnya juga terkait langsung dengan akses mekanisme struktur dari masyarakat PIR, kebun campuran dan para rimbo.

Berdasarkan klasifikasi hak kepemilikan di KPHP Meranti dapat dijelaskan, sebagai berikut: a) Hak akses (access), berupa: masyarakat lokal, pengunjung, tamu perusahaan,wisatawan hutan, pelintas sarana jalan perusahaan atau pemukiman; b) Hak pemanfaatan (withdrawal) terdapat pada pengguna yang mendapatkan izin konsesi HPH, HTI, HTR; c) Hak pengelolaan (management) terdapat pada KPHP Meranti; d) Hak untuk menentukan (exclusion) terdapat pada dinas kehutanan provinsi atau dinas kehutanan kabupaten; dan e) Hak mencabut (alienation) terdapat pada Kementerian Kehutanan (Kartodihardjo, 2007). Posisi dan status pengguna (bundle of rights) terkait tumpang tindih lebih banyak terjadi di areal

Tabel 6. Hak kepemilikan dan tumpang-tindih hak pada wilayah tertentu Table 6. Property rights and overlapping in particularly areas

\begin{tabular}{|c|c|c|c|c|c|}
\hline \multirow[b]{2}{*}{ Pengguna (User) } & \multicolumn{5}{|c|}{$\begin{array}{l}\text { Tumpang tindih hak pemanfaatan } \\
\text { (Utilization overlapping users) }\end{array}$} \\
\hline & $\begin{array}{l}\text { Pemilik } \\
\text { (Owner) }\end{array}$ & $\begin{array}{l}\text { Pengguna ilegal } \\
\text { (Illegal user) }\end{array}$ & $\begin{array}{c}\text { Pengunaan tidak } \\
\text { prosedur } \\
\text { (not procedural using) }\end{array}$ & $\begin{array}{l}\text { Hutan adat } \\
\text { (Customary } \\
\text { forest) }\end{array}$ & $\begin{array}{c}\text { Penyewa } \\
\text { (Rent) }\end{array}$ \\
\hline Pemukiman & $\sqrt{ }$ & $\sqrt{ }$ & - & $\sqrt{ }$ & $\sqrt{ }$ \\
\hline Kebunan campuran & $\sqrt{ }$ & $\sqrt{ }$ & - & $\sqrt{ }$ & $\sqrt{ }$ \\
\hline \multicolumn{6}{|c|}{ Perkebunan Non Prosedural } \\
\hline PT. Pinago Utama & $\sqrt{ }$ & $\sqrt{ }$ & $\sqrt{ }$ & - & - \\
\hline PT. BSS & $\sqrt{ }$ & $\sqrt{ }$ & $\sqrt{ }$ & $\sqrt{ }$ & - \\
\hline PT. MBI & $\sqrt{ }$ & $\sqrt{ }$ & $\sqrt{ }$ & $\sqrt{ }$ & - \\
\hline PT. PTPN VII & $\sqrt{ }$ & $\sqrt{ }$ & $\sqrt{ }$ & - & - \\
\hline
\end{tabular}

Keterangan : $\sqrt{ }=$ terdapat

Sumber (Source) : Diolah dari data lapangan, 2015, dan modifikasi Schalager dan Ostrom, 1992 (Processed from field collecting, 2015, and modified from Schlager dan Ostrom, 1992) 
Tabel 7 Posisi dan status pengguna di areal konsesi

Table 7 Bundle of rigths and user position in concession areas

\begin{tabular}{|c|c|c|c|c|c|c|c|}
\hline \multirow{2}{*}{$\begin{array}{c}\text { Klasifikasi } \\
\text { pengguna } \\
\text { (User } \\
\text { classification) }\end{array}$} & \multicolumn{7}{|c|}{$\begin{array}{c}\text { Posisi dan status pengguna } \\
\text { (Bundle of rights and position user) }\end{array}$} \\
\hline & $\begin{array}{l}\text { Pemu- } \\
\text { kiman } \\
\text { (Settle- } \\
\text { ment) }\end{array}$ & $\begin{array}{c}\text { Kebun } \\
\text { (Owner } \\
\text { plantation) }\end{array}$ & $\begin{array}{l}\text { Tambang } \\
\text { ilegal } \\
\text { (Illegal } \\
\text { mining) }\end{array}$ & $\begin{array}{l}\text { Tambang } \\
\text { resmi } \\
\text { (Legal } \\
\text { mining) }\end{array}$ & $\begin{array}{l}\text { Hak ulayat } \\
\text { (Claim } \\
\text { community) }\end{array}$ & $\begin{array}{c}\text { HTI/ } \\
\text { IPPKH } \\
(I F P / \\
P P K H)\end{array}$ & $\begin{array}{l}\text { Penyewa } \\
\text { (Rent) }\end{array}$ \\
\hline Hak akses (access) & $\sqrt{ }$ & $\sqrt{ }$ & $\sqrt{ }$ & $\sqrt{ }$ & $\sqrt{ }$ & $\sqrt{ }$ & $\sqrt{ }$ \\
\hline \multicolumn{8}{|c|}{ Hak pemanfaatan (withdrawal) } \\
\hline \multicolumn{8}{|c|}{ Izin Usaha Kehutanan } \\
\hline PT. REKI & $\sqrt{ }$ & $\sqrt{ }$ & - & - & $\sqrt{ }$ & $\sqrt{ }$ & - \\
\hline PT RHM & $\sqrt{ }$ & $\sqrt{ }$ & - & $\sqrt{ }$ & $\sqrt{ }$ & $\sqrt{ }$ & - \\
\hline PT. BPP-II & $\sqrt{ }$ & $\sqrt{ }$ & - & $\sqrt{ }$ & - & $\sqrt{ }$ & - \\
\hline PT. BBP-I & $\sqrt{ }$ & $\sqrt{ }$ & $\sqrt{ }$ & $\sqrt{ }$ & $\sqrt{ }$ & $\sqrt{ }$ & $\sqrt{ }$ \\
\hline PT. SBB & $\sqrt{ }$ & $\sqrt{ }$ & $\sqrt{ }$ & $\sqrt{ }$ & $\sqrt{ }$ & $\sqrt{ }$ & $\sqrt{ }$ \\
\hline PT. WAM & $\sqrt{ }$ & $\sqrt{ }$ & - & - & - & - & - \\
\hline Eks PT. Pakerin & $\sqrt{ }$ & $\sqrt{ }$ & - & $\sqrt{ }$ & $\sqrt{ }$ & $\sqrt{ }$ & $\sqrt{ }$ \\
\hline Kel. Sarolangun & $\sqrt{ }$ & $\sqrt{ }$ & - & - & - & - & - \\
\hline \multicolumn{8}{|l|}{ Tambang Batu Bara } \\
\hline PT. Mensa Bara B. & - & $\sqrt{ }$ & - & - & - & $\sqrt{ }$ & - \\
\hline PT. Persada MJ & - & $\sqrt{ }$ & - & - & - & $\sqrt{ }$ & - \\
\hline PT. Lais Coal M. & $\sqrt{ }$ & - & - & - & - & $\sqrt{ }$ & - \\
\hline PT. Andalan SA & - & - & - & - & - & $\sqrt{ }$ & - \\
\hline PT. Duta Alam E & - & $\sqrt{ }$ & - & - & - & $\sqrt{ }$ & - \\
\hline PT. Muba Coal M. & - & $\sqrt{ }$ & - & - & - & $\sqrt{ }$ & - \\
\hline PT. Sentosa K E & - & $\sqrt{ }$ & - & - & - & $\sqrt{ }$ & - \\
\hline \multicolumn{8}{|l|}{ Minyak-Gas/Pipa } \\
\hline Conoco & - & $\sqrt{ }$ & - & - & - & $\sqrt{ }$ & - \\
\hline Phillips & - & $\sqrt{ }$ & - & - & - & $\sqrt{ }$ & - \\
\hline $\begin{array}{l}\text { PT. Sele Raya M D } \\
\text { Per.Gas Negara }\end{array}$ & - & $\sqrt{ }$ & - & - & - & $\sqrt{ }$ & - \\
\hline \multicolumn{8}{|c|}{ Kelompok Masyarakat } \\
\hline Desa Sako suban & $\sqrt{ }$ & $\sqrt{ }$ & - & - & $\sqrt{ }$ & $\sqrt{ }$ & $\sqrt{ }$ \\
\hline Desa Bintialo & $\sqrt{ }$ & $\sqrt{ }$ & $\sqrt{ }$ & $\sqrt{ }$ & - & $\sqrt{ }$ & $\sqrt{ }$ \\
\hline Desa Pgkln Bulian & $\sqrt{ }$ & $\sqrt{ }$ & $\sqrt{ }$ & - & - & $\sqrt{ }$ & $\sqrt{ }$ \\
\hline Desa Talang uluh & $\sqrt{ }$ & $\sqrt{ }$ & - & - & - & $\sqrt{ }$ & $\sqrt{ }$ \\
\hline Desa Tpg Baru & $\sqrt{ }$ & $\sqrt{ }$ & - & - & - & $\sqrt{ }$ & $\sqrt{ }$ \\
\hline Desa Pagar Desa & $\sqrt{ }$ & $\sqrt{ }$ & - & - & - & $\sqrt{ }$ & $\sqrt{ }$ \\
\hline Desa P.Bayat & $\sqrt{ }$ & $\sqrt{ }$ & $\sqrt{ }$ & - & - & $\sqrt{ }$ & $\sqrt{ }$ \\
\hline Desa Bayat Ilir & $\sqrt{ }$ & $\sqrt{ }$ & - & - & - & $\sqrt{ }$ & $\sqrt{ }$ \\
\hline Guci B. Semandai & $\sqrt{ }$ & $\sqrt{ }$ & - & $\sqrt{ }$ & - & $\sqrt{ }$ & - \\
\hline
\end{tabular}

Keterangan: $\sqrt{ }=$ terdapat

Sumber (Source) : Diolah dari data lapangan, 2015, dan modifikasi Schalager dan Ostrom, 1992 (Processed from field collecting, 2015, and modified from Schlager dan Ostrom, 1992) 
izin konsesi. Tumpang tindih merupakan permasalahan yang kompleks dan memiliki potensi konflik sebagaimana dijelaskan Dhiaulhaq et al. (2014); Hyde, (2016); Kant, Vertinsky \& Zheng (2016); dan Zhang, (2016).

\section{Legalitas dan Status Pengguna}

Analisis legalitas pengguna pada kawasan HP Meranti, dilihat dari ada tidaknya dasar hukum penggunaan. Akses legal merupakan akses yang memiliki izin dan sesuai dengan prosedural, sedangkan akses ilegal adalah akses yang tidak berizin atau memiliki izin tetapi tidak sesuai prosedural. Tumpang tindih akses legal dan ilegal mengakibatkan ketidakjelasan hak kepemilikan dalam kawasan hutan pada wilayah KPHP Meranti antara pemanfaatan lahan yang telah dikuasai masyarakat dan areal izin usaha. Hasil analisis citra dari overlay peta izin usaha, diperkirakan tumpang tindih lahan seluas 94.016 hektar atau 38,53\% dari luas kawasan. Seluas 29.595 hektar atau sebesar $12,13 \%$ dari luas wilayah KPHP dari area yang tumpang tindih merupakan akses ilegal. Legalitas akses dan status pengguna lahan berdasarkan kolompok hutan dapat dilihat pada Tabel 8 .

\section{E. Tipologi Pengguna}

$\begin{array}{ccc}\text { Pengguna } & \text { yang } & \text { berbeda-beda, } \\ \text { mengakibatkan } & \text { tipologi } & \text { penggunaan }\end{array}$
kawasan di KPHP Meranti sangat beragam. Pengelompokkan pengguna dilakukan dari bentuk kegiatan/usaha yang dilakukan, yaitu pemilik lahan pemukiman, pemilik lahan kebun skala kecil, pemilik kebun skala besar, pertambangan ilegal, pertambangan legal, izin prosedural, hak ulayat dan penyewa. Status dan posisi pengguna yang berbeda-beda menjadi dasar klasifikasi tipologi penggunaan. Untuk menjelaskan tipologi penggunaan perlu mengetahui parameter antara lain, a) bentuk pemanfaatan, b) kegiatan, c) individu/ kelompok atau organisasi, d) jenis izin usaha, e) pemberi wewenang/lembaga pengatur, f) batasan waktu, dan g) hak dan kewajiban.
Kaitan penggunaan dan parameter yang dianalisis terkait pemanfaatan kawasan hutan, akan memberi gambaran tipologi penggunaan dan kaitannya dengan tumpangtindih kepemilikan. Pengamatan lapangan menunjukan, bahwa selain permasalahan klaim lahan adat, faktor terjadinya konflik akibat tumpang-tindih lahan dapat juga disebabkan oleh adanya kesamaan jenis komoditi usaha dan ketidakdisiplinan terhadap jangka waktu perizinan, sebagai contoh:

- Kesamaan jenis komoditi tanaman karet antara milik rakyat dan pemegang izin konsesi HTI. Hal ini menimbulkan motivasi masyarakat untuk mengokupasi kawasan hutan untuk menanam karet. Tanggapan masyarakat adalah;

"Jika perusahaan bisa menanam karet kenapa masyarakat dilarang menanam karet di kawasan hutan".

(Zulkarnain 54 tahun, Desa Sako Suban)

- Penggunaan kawasan hutan oleh pemegang izin usaha yang melebihi batas waktu perizinan, memunculkan aksi sepihak masyarakat untuk mengokupasi lokasi perizinan. Tanggapan masyarakat adalah;

"Perusahaan itukan sudah habis batas waktu izinnya, tetapi masih beroperasi, artinya kami juga bisa memanfaatkan lahan itu"

(Teguh 65 tahun, Desa Peninggalan) Tipologi penggunaan sebagaimana terlihat pada Tabel 9.

Pada Tabel 8, terlihat bahwa exclusion lahan dikawasan hutan bukan saja oleh pemerintah (Menteri KLHK/gubernur/ bupati) tetapi juga masyarakat setempat melalui tokoh masyarakat dan/atau kepala desa sebagai pemilik hak otoritas (Authority right). Para pemilik hak otoritas dan exclusion yang dapat mengekslusi pengguna lain dapat dikelompokkan dan dijelaskan sebagai berikut:

a) Mantan pesirah, kepala desa dan tokoh masyarakat, menyuruh masyarakat/ 
Tabel 8 Legalitas akses dan status pengguna

Table 8 Legality of access and user status

\begin{tabular}{|c|c|c|c|}
\hline $\begin{array}{l}\text { Kelompok Hutan } \\
\text { (Forest groups) }\end{array}$ & $\begin{array}{c}\text { Luas/Hektar } \\
\text { (Areas/Hectare) }\end{array}$ & $\begin{array}{c}\text { Akses legal } \\
\text { (Legal access) }\end{array}$ & $\begin{array}{c}\text { Akses ilegal } \\
\text { (Illegal access) }\end{array}$ \\
\hline $\begin{array}{l}\text { HP Meranti } \\
\text { Sungai Bayat } \\
\text { (HP) }\end{array}$ & 120 & IUIPHHK PT. BPP-I & $\begin{array}{l}\text { PT. Daffah Tri Utama (izin tanpa } \\
\text { prosedural) dan kebun masyarakat } \\
\text { dan pemukiman }\end{array}$ \\
\hline $\begin{array}{l}\text { HPK Meranti } \\
\text { Sungai Bayat } \\
\text { (HPK) }\end{array}$ & 8.785 & $\begin{array}{l}\text { Eks IUPHHK-HT PT. Pakerin } \\
\text { dan izin usaha pertambangan } \\
(6.254 \text { hektar) }\end{array}$ & $\begin{array}{l}\text { Kebun campuran, pemukiman } \\
\text { sebagai pemilik lahan. }\end{array}$ \\
\hline $\begin{array}{l}\text { HPT Meranti } \\
\text { Lubuk Buah } \\
\text { (HPT) }\end{array}$ & 6.586 & $\begin{array}{l}\text { Wilayah Tertentu KPHP dan } \\
\text { izin usaha pertambangan } \\
\text { PT. Madhucon Indonesia, } \\
\text { transmigrasi. }\end{array}$ & $\begin{array}{l}\text { PT. MBI (perkebunan izin tanpa } \\
\text { prosedural), pemukiman, lahan } \\
\text { pertanian masyarakat, sarana } \\
\text { umum (sekolah, kantor Kades) }\end{array}$ \\
\hline $\begin{array}{l}\text { HP Meranti } \\
\text { Sungai Merah } \\
\text { (HP) }\end{array}$ & 4.976 & $\begin{array}{l}\text { Wilayah Tertentu KPHP, } \\
\text { IUIPHHK HTI PT. SBB, } \\
\text { IUP PT. Muba Coal Mine, } \\
\text { MIGAS-Conoco P Ltd, Eks } \\
\text { IUPHHK-HT PT. Pakerin }\end{array}$ & $\begin{array}{l}\text { PT. Pinago Utama (izin tanpa } \\
\text { prosedural) seluas } 4.488 \text { Hektar, } \\
\text { pemukiman, kebun, pertanian } \\
\text { masyarakat dan sarana umum }\end{array}$ \\
\hline $\begin{array}{l}\text { HPT/K Meranti } \\
\text { Sungai Kapas }\end{array}$ & 3.812 & $\begin{array}{l}\text { Wilayah Tertentu KPHP, Eks } \\
\text { IUPHHK-HT PT. Pakerin. }\end{array}$ & $\begin{array}{l}\text { PT. Pinago Utama seluas }(1.150 \\
\text { Hektar), pemukiman, kebun, } \\
\text { pertanian masyarakat, sarana } \\
\text { umum. }\end{array}$ \\
\hline $\begin{array}{l}\text { HP Guci Buring } \\
\text { Semandai }\end{array}$ & 5.316 & $\begin{array}{l}\text { KPHP Meranti, Jalur pipa } \\
\text { Minyak dan Gas. }\end{array}$ & $\begin{array}{l}\text { Perumahan PTPN VII (ada } \\
\text { Sertifikat Hak Milik), Plasma } \\
\text { PTPN VII (NES IV), pemukiman } \\
\text { ada SHM, kebun masyarakat, } \\
\text { perkebunan PTPN VII }\end{array}$ \\
\hline
\end{tabular}

Sumber (Source): Data lapangan, 2015, dan usulan RTRWP Dinas Kehutanan Provinsi Sumatera Selatan, 2012 (Processed from field collecting, 2015, and recommendation RTRWP from Forest Service South Sumatra Province, 2012)

keluarga untuk memanfaatkan kawasan hutan. Wewenang berdasarkan adanya patron-klien, budaya dan ikatan sosial, di dalamnya ada berbagai motif kepentingan antara lain; ekonomi (jual-beli), kuatnya adat istiadat, serta kultur budaya masyarakat setempat;

b) Pemerintah daerah (bupati/gubernur), pemberian izin sesuai hukum dan perundangan (prosedural) pada izin usaha pertambangan, namun ada juga yang non prosedural memberikan izin perkebunan Hak Guna Usaha (HGU) di dalam kawasan hutan. Modus ini biasanya dengan alasan kesalahan teknis (batas kawasan) atau kesalahan terstruktur. Namun ada juga yang sengaja dilakukan dengan motif keuntungan pribadi;

c) Menteri Lingkungan Hidup dan Kehutanan (LHK) memberikan izin pemanfaatan atau izin konsesi pada Hutan Tanaman Industri (HTI), dan Restorasi ekosistem (RE) atau izin pinjam pakai kawasan hutan (IPPHK), berdasarkan wewenang sesuai aturan hukam dan perundangan yang berlaku.

Akses dari ketiga kelompok tersebut, mengakibatkan tumpang-tindih pemanfaatan dan hak kepemilikan. Tidak jarang kepentingan dan pengaruh yang dimiliki masing-masing pihak, dapat mengakibatkan benturan atau konflik pemanfaatan kawasan 
Tabel 9. Tipologi penggunaan kawasan hutan

Table 9. Typology of using in forest areas

\begin{tabular}{|c|c|c|c|c|c|c|}
\hline $\begin{array}{c}\text { Pemanfaatan } \\
\text { lahan } \\
\text { (Land } \\
\text { Utilization) }\end{array}$ & $\begin{array}{l}\text { Kegiatan } \\
\text { (Activity) }\end{array}$ & $\begin{array}{c}\text { Individu/ } \\
\text { organisasi } \\
\text { (Individu/ } \\
\text { organization) }\end{array}$ & $\begin{array}{l}\text { Jenis usaha } \\
\text { (Type of } \\
\text { business) }\end{array}$ & $\begin{array}{c}\text { Pemberi } \\
\text { wewenang } \\
\text { (Authority) }\end{array}$ & $\begin{array}{c}\text { Batas } \\
\text { waktu } \\
\text { (Deadline) }\end{array}$ & $\begin{array}{c}\text { Kewajiban } \\
\text { (Obligations) }\end{array}$ \\
\hline Permukiman & $\begin{array}{l}\text { Membuat rumah } \\
\text { tempat tinggal }\end{array}$ & $\begin{array}{l}\text { Masyarakat asli } \\
\text { dan pendatang }\end{array}$ & Tidak ada & Kepala desa & Tidak ada & $\begin{array}{l}\text { Membayar } \\
\text { pajak }\end{array}$ \\
\hline $\begin{array}{l}\text { Kebun } \\
\text { skala besar } \\
\text { (perusahaan) }\end{array}$ & $\begin{array}{l}\text { Kebun sawit atau } \\
\text { karet }\end{array}$ & $\begin{array}{l}\text { Perusahaan (PT/ } \\
\mathrm{CV})\end{array}$ & $\mathrm{PT} / \mathrm{CV}$ & Bupati & $\begin{array}{l}\text { HGU } \\
\text { waktu 20- } \\
30 \text { tahun }\end{array}$ & $\begin{array}{l}\text { PBB Tanah } \\
\text { Restribusi } \\
\text { Daerah }\end{array}$ \\
\hline $\begin{array}{l}\text { Kebun } \\
\text { Skala kecil } \\
\text { (masyarakat) }\end{array}$ & $\begin{array}{l}\text { Karet, sawit atau } \\
\text { kebun campuran, } \\
\text { dan palawija }\end{array}$ & $\begin{array}{l}\text { Individu } \\
\text { masyarakat } \\
\text { dan kelompok } \\
\text { masyarakat }\end{array}$ & $\begin{array}{l}\text { Tidak ada } \\
\text { bentuk } \\
\text { jenis usaha }\end{array}$ & $\begin{array}{l}\text { Kepala desa } \\
\text { tanpa pemberi } \\
\text { izin/ } \\
\text { wewenang }\end{array}$ & $\begin{array}{l}\text { Batas bagi } \\
\text { masyarakat } \\
\text { tidak ada } \\
\text { batas } \\
\text { waktu }\end{array}$ & $\begin{array}{l}\text { Kewajiban } \\
\text { bayar pajak } \\
\text { tanah (tidak } \\
\text { ada dasar } \\
\text { pemungutan) }\end{array}$ \\
\hline $\begin{array}{l}\text { Tambang } \\
\text { ilegal } \\
\text { (PETI) }\end{array}$ & $\begin{array}{l}\text { Pertambangan ilegal } \\
\text { bekas galian minyak } \\
\text { dan pemasakan } \\
\text { (ekstraksi) }\end{array}$ & $\begin{array}{l}\text { Individu } \\
\text { masyarakat } \\
\text { dan kelompok } \\
\text { masyarakat }\end{array}$ & $\begin{array}{l}\text { Tidak ada } \\
\text { (omset } \\
1-5 \text { milyar) }\end{array}$ & $\begin{array}{l}\text { Kelompok } \\
\text { masyarakat } \\
\text { (tokoh atau } \\
\text { kepala desa }\end{array}$ & tidak ada & $\begin{array}{l}\text { Membayar } \\
\text { iuran bagi } \\
\text { tokoh/aparat } \\
\text { tertentu }\end{array}$ \\
\hline $\begin{array}{l}\text { Tambang } \\
\text { resmi } \\
\text { (izin pinjam } \\
\text { pakai) }\end{array}$ & $\begin{array}{l}\text { Membuka tambang } \\
\text { (mineral, ninyak } \\
\text { dan gas) } \\
\text { eksplorasi/ } \\
\text { eksploitasi }\end{array}$ & $\begin{array}{l}\text { Perusahaan } \\
\text { swasta nasional, } \\
\text { patungan maupun } \\
\text { BUMN/ BUMD }\end{array}$ & $\begin{array}{l}\mathrm{PT} / \mathrm{CV} \\
\text { maupun } \\
\text { BUMN/ } \\
\text { BUMD }\end{array}$ & $\begin{array}{l}\text { Izin tambang } \\
\text { bupati, izin } \\
\text { pinjam pakai } \\
\text { dari KLHK }\end{array}$ & $\begin{array}{l}\text { Eksplorasi } \\
2-5 \text { tahun } \\
\text { Eksploitasi } \\
10-15 \\
\text { tahun }\end{array}$ & $\begin{array}{l}\text { Bayar pajak, } \\
\text { izin usaha, } \\
\text { izin usaha } \\
\text { pinjam } \\
\text { pakai, PNBP, } \\
\text { kewajiban } \\
\text { pihak ketiga) }\end{array}$ \\
\hline $\begin{array}{l}\text { Areal konsesi } \\
\text { HTI }\end{array}$ & $\begin{array}{l}\text { Eksploitasi kayu } \\
\text { alam dengan Tebang } \\
\text { Habis Permudaan } \\
\text { Buatan (THPB) } \\
\text { penanaman karet, } \\
\text { akasia, jabon. }\end{array}$ & Perusahaan HTI & $\begin{array}{l}\text { IUIPHHK } \\
\text { - HT }\end{array}$ & KLHK & $\begin{array}{l}60-100 \\
\text { tahun } \\
\text { (PT. WAM } \\
60 \text { th ) }\end{array}$ & $\begin{array}{l}\text { Membayar } \\
\text { iuran usaha } \\
\text { pemanfaatan } \\
\text { (IUPH) } \\
\text { PSDH dan } \\
\text { DR }\end{array}$ \\
\hline $\begin{array}{l}\text { Pengakuan } \\
\text { memiliki hak } \\
\text { ulayat }\end{array}$ & $\begin{array}{l}\text { Penguasaan lahan } \\
\text { dengan bukti } \\
\text { memiliki kebun } \\
\text { para rimbo }\end{array}$ & $\begin{array}{l}\text { Suku asli Desa } \\
\text { Sako Suban, } \\
\text { Bayat L. Bintialo, } \\
\text { dan Talang Uluh }\end{array}$ & Tidak ada & $\begin{array}{l}\text { Mantan } \\
\text { pesirah (Patron } \\
\text { bagi suku } \\
\text { Musi, dan } \\
\text { suku kubu) }\end{array}$ & Tidak ada & Tidak ada \\
\hline $\begin{array}{l}\text { Areal konsesi } \\
\text { lain (HTR) }\end{array}$ & $\begin{array}{l}\text { Tanaman keras } \\
\text { berpohon selain } \\
\text { sawit }\end{array}$ & $\begin{array}{l}\text { Kelompok } \\
\text { masyarakat }\end{array}$ & IUIHTR & KLHK & $\begin{array}{l}35 \text { th dan } \\
\text { perpan- } \\
\text { jang }\end{array}$ & $\begin{array}{l}\text { PNBP } \\
\text { (PSDH-DR) }\end{array}$ \\
\hline $\begin{array}{l}\text { Izin pinjam } \\
\text { pakai lainya }\end{array}$ & $\begin{array}{l}\text { Telekomunikasi, } \\
\text { listrik dan irigasi }\end{array}$ & $\begin{array}{l}\text { Pemerintah, } \\
\text { perusahaan jasa/ } \\
\text { swasta }\end{array}$ & IPHHK & KLHK & $\begin{array}{l}10-15 \text { th } \\
\text { atau } \\
\text { selesai } \\
\text { pekerjaan }\end{array}$ & $\begin{array}{l}\text { Iuran usaha } \\
\text { pemanfaatan } \\
\text { (IUPH) } \\
\text { pengganti } \\
\text { nilai tegakan }\end{array}$ \\
\hline Penyewa & $\begin{array}{l}\text { Lahan pembakaran } \\
\text { minyak PETI }\end{array}$ & $\begin{array}{l}\text { Kelompok } \\
\text { masyarakat }\end{array}$ & $\begin{array}{l}\text { Individu/ } \\
\text { kelompok }\end{array}$ & $\begin{array}{l}\text { Kadesa/tokoh } \\
\text { masyarakat }\end{array}$ & $1-2$ th & Tidak ada \\
\hline
\end{tabular}

Sumber (Source): Diolah dari data lapangan, 2015 (Processed from field collecting, 2015) 


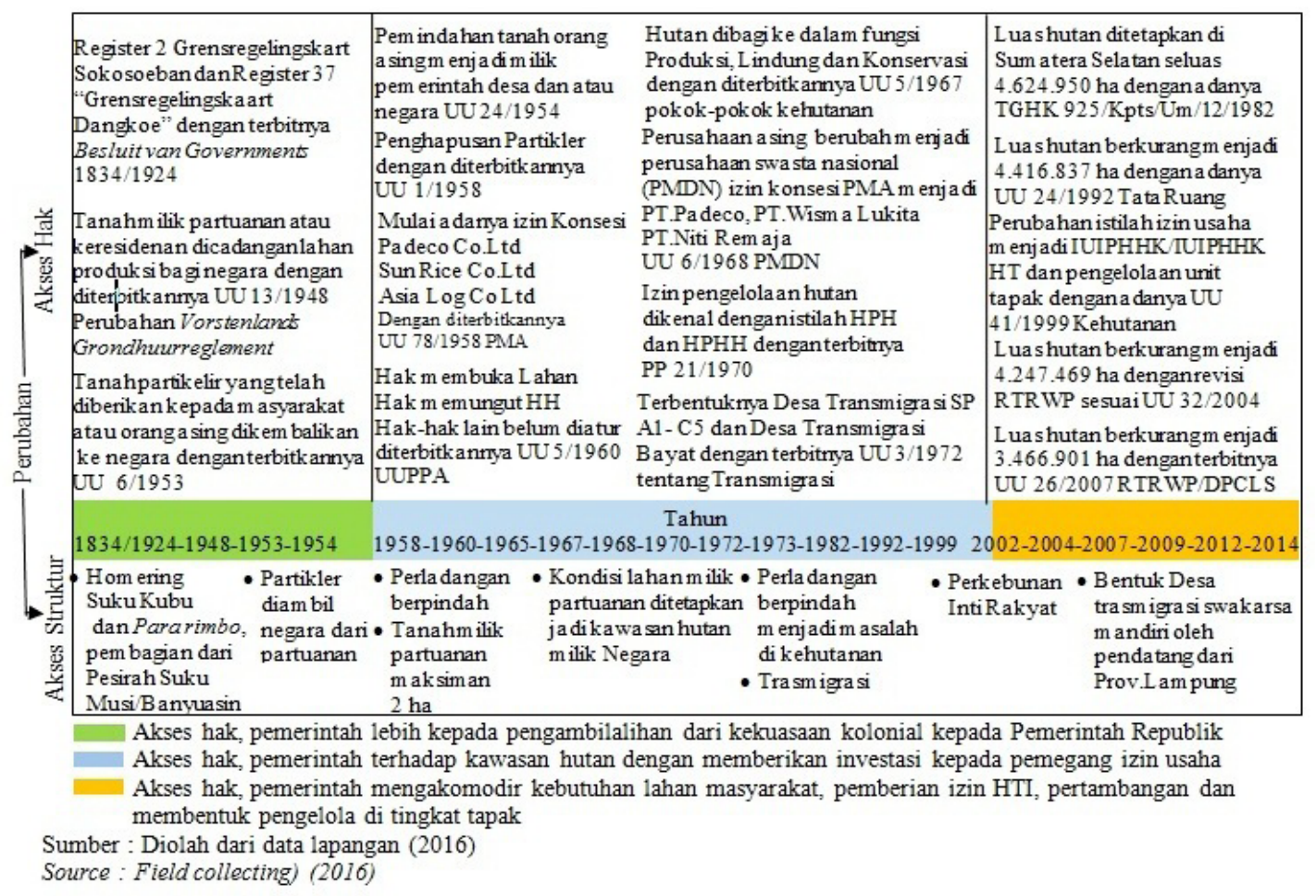

Gambar 2. Perubahan akses yang terjadi di KPHP Meranti 1834/1924-2014

Figure 2. Access change in FMU Meranti 1983/1924-2014

hutan. Gambaran perubahan akses kawasan hutan dari mekanisme hak dan struktur di KPHP Meranti sejak era kolonial sampai saat ini (1924-2014) disajikan sebagaimana Gambar 2.

\section{KESIMPULAN DAN SARAN}

\section{A. Kesimpulan}

Bagaimana semua pihak mendapatkan akses untuk memanfaatkan kawasan hutan dapat dijelaskan dengan teori akses yang dikembangan oleh Ribot dan Peluso ( 2003). Adanya akses hak dan struktur yang tidak terkendali mengakibatkan kompleksitas permasalahan hak kepemilikan di KPHP Meranti. Akses mekanisme hak dengan pemberian istilah baru seperti HTI, RE, HTR, IPHHK dalam pengelolaan hutan di KPHP Meranti telah memaksa pihak lain (masyarakat) untuk keluar atau menjadi ilegal.

Pemberian akses mekanisme hak, cenderung tidak memerhatikan kondisi biofisik lapangan, kondisi ekonomi masyarakat dan adat istiadat masyarakat suku Kubu dan Musi pada saat izin diberikan. Akses mekanisme hak yang tidak memerhatikan kondisi lapangan, mengakibatkan sengketa antara pemilik izin usaha dengan masyarakat sebagai pemilik lahan yang diperoleh dari mekanisme struktur, sebagaimana yang terjadi antara masyarakat suku Kubu dan suku Musi dengan PT. SBB dan PT BPP I dan II. Kondisi ini disebabkan masyarakat menjadi ilegal di tanah atau kampungnya sendiri.

Hasil analisis hak kepemilikan dan status pengguna dapat dijelaskan bahwa terdapat 6 (enam) izin usaha HTI/RE dan 5 (lima) izin usaha perkebunan non prosedural, serta 10 izin pinjam pakai kawasan hutan (IPHHK) pertambangan minyak dan gas, pertambangan mineral batu bara, dan izin jaringan listrik, telekomunikasi dan irigasi dari akses mekanisme hak (izin). Terdapat lima bentuk akses mekanisme struktur, yaitu; a) Akses dari wilayah jelajah (homering) suku Kubu; b) Para rimbo suku Musi; c) Perladangan berpindah; d) Perkebunan Inti 
Rakyat (PIR); dan e) Desa transmigrasi ilegal karena pendatang dari Lampung yang tersebar di seluruh wilayah kerja KPHP Meranti. Hasil analisis citra, peta izin usaha dan wilayah kelola masyarakat menyebabkan perkiraan luas tumpang-tindih pemanfaatan dari klaim lahan, permukiman dan izin tanpa prosedural seluas \pm 94.016 hektar $(38,53 \%)$ dari luas kawasan, yang terdiri atas 64.421 hektar $(68,52 \%)$ merupakan klaim lahan di izin konsesi dan \pm 29.595 hektar $(12,13 \%$ merupakan izin tidak sesuai prosedural yang dimiliki 5 (lima) perkebunan Sawit. Hasil penelitian juga menjelaskan bahwa kepentingan dan pengaruh para pihak sangat besar dalam perebutan pemanfaatan kawasan hutan di KPHP Meranti.

\section{B. Saran}

a) Perubahan pengelolaan kawasan, seperti nama kegiatan dalam kegiatan kehutanan, sebaiknya memerhatikan kondisi fisik lapangan, kondisi ekonomi sosial masyarakat dan adat istiadat setempat. Perubahan pengelolaan dapat mengakibatkan perbedaan cara pandang para pengguna dan menimbulkan akses baru.

b) Perlu keterlibatan masyarakat dalam menentukan perubahan pengelolaan kawasan hutan dalam penentuan siapa pengguna, apa yang dimanfaatkan, cara menggunakan dan penentuan pembagian hasil (kontribusi) dari hasil hutan yang diambil.

\section{UCAPAN TERIMA KASIH (ACKNOWLEDGMENT)}

Terima kasih kepada Pusat Pendidikan dan Pelatihan Sumber Daya Manusia Kementerian Lingkungan Hidup dan Kehutanan, Kepala Kesatuan Pengelolan Hutan Produksi (KPHP) Meranti, Balai Pemantauan Hutan Produksi Wilayah V Palembang, Dinas Kehutanan Kabupaten Musi Banyuasin, Dinas Kehutanan Provinsi-Sub Dinas (Subdin) Planologi.

\section{DAFTAR PUSTAKA}

Dhiaulhaq, A., Gritten, D., De Bruyn, T., Yasmi, Y., Zazali, A., \& Silalahi, M. (2014). Transforming conflict in plantations through mediation: Lessons and experiences from Sumatera, Indonesia. Forest Policy and Economics, 41 (2014), 22-30. https://doi. org/10.1016/j.forpol.2014.01.003

Dolšak, N., \& Ostrom, E. (2003). The challenges of the commons. In Dolšak, N., \& Ostrom, E. (Eds). The commons in the new millennium : Challenges and adaptation. Cambridge (Massachusetts): The MIT Press. https:// doi.org/10.1007/s11077-005-2857-5

Febryano, I.G., Suharjito, D., Darusman, D., Kusmana, C., \& Hidayat, A. (2015). Aktor dan relasi kekuasaan dalam pengelolaan mangrove di Kabupaten Pesawaran, Provinsi Lampung, Indonesia. Jurnal Analisis Kebijakan Kehutanan, 12(2), 123-138.

Fennell, L.A. (2011). Ostrom's law: Property rights in the commons. International Journal of the Commons, 5(1), 9-27.

Gamin, G., Kartodihardjo, H., Kolopaking, L.M. \& Boer, R. (2014). Menyelesaikan konflik penguasaan kawasan hutan melalui pendekatan gaya sengketa para pihak di Kesatuan Pengelolaan Hutan Lakitan. Jurnal Analisis Kebijakan Kehutanan, 11(1), 71 - 90.

Galudra, G., Sirait, M., Pasya, G., Fay, C., Suyanto, van Noordwijk, M., \& Pradhan, U. (2010). RaTA: rapid land tenure assessment manual for identifying the nature of land tenure conflicts. Bogor: World Agroforestry Centre.

Hendricks, W. (1991). How to manage conflict: A practical guide to effective conflict management. Shawnee Mission, Kansas: National Press Publications.

Hyde, W.F. (2016). Whereabouts devolution and collective forest management ? Forest Policy and Economics, 72, 85-91.

Ingram, J.C., Wilkie, D., Clements, T., McNab, R.B., Nelson, F., Baur, E.H....... Foley, C.A.H. (2014). Evidence of payments for ecosystem services as a mechanism for supporting biodiversity conservation and rural livelihoods. Ecosystem Services, 7, 10-21. https://doi.org/10.1016/j.ecoser.2013.12.003

Kant, S., Vertinsky, I., \& Zheng, B. (2016). Valuation of first nations peoples's social, cultural, and land use activities using life satisfaction approach. Forest Policy and Economics, 72, 46-55. https://doi.org/10.1016/j.forpol.2016.06.014 
Karsudi, Soekmadi, R., \& Kartodihardjo, H. (2010). Model pengembangan kelembagaan pembentukan wilayah Kesatuan Pengelolaan Hutan di Provinsi Papua. Jurnal Manajemen Hutan Tanaman, XVI(2), 92-100.

Kartodihardjo, H. (2007). Dibalik kerusakan hutan dan bencana alam. Masalah transformasi kebijakan kehutanan. Jakarta: KEHATI.

Kartodihardjo, H. (2013). Masalah cara pikir dan praktek kehutanan: Refleksi dan evaluasi II. In Kartodihardjo H (Ed.), Kembali ke jalan lurus: Kritik penggunaan ilmu dan praktek kehutanan. Bogor: Forci Development.

Larson, A., \& Pulhin, J. (2012). Enhancing forest tenure reforms through more responsive regulations. Conservation and Society, 10(2), 103. https:// doi.org/10.4103/0972-4923.97482

Ministry of Forestry. (2008). Reducing emissions from deforestation and forest degradation in Indonesia. Bogor: FORDA.

Mulyaningrum, Kartodihardjo, H. Jaya, I.N.S., \& Nurgroho, B. (2013). Stakeholders analysis of policy-making process: the case of timber legality policy on private forest. Jurnal Manajemen Hutan Tropika, XIX(2), 156-162.

Mutolib, A., Yonariza, Mahdi, \& Ismono, H. (2015). Konflik agraria dan pelepasan tanah ulayat (Studi kasus pada masyarakat suku melayu di Kesatuan Pemangkuan Hutan Dharmasraya, Sumatera Barat). Jurnal Penelitian Sosial dan Ekonomi Kehutanan, 12(3), 213-225.

Nugroho, B. (2013). Reformasi kelembagaan dan tata kepemerintahan: Faktor pemungkin menuju tata kelola kehutanan yang baik. In Kartodihardjo, H. (Ed.). Kembali ke jalan lurus: Kritik penggunaan ilmu dan praktek kehutanan. Bogor: Forci Development..

Nurtjahjawilasa, Kartodihardjo, H., Nurrochmat, D.R., Justianto, A. (2015). Analisis pemangku kepentingan dalam kebijakan pengelolaan dan pengembangan sumber daya manusia kehutanan. Jurnal Penelitian Sosial dan Ekonomi Kehutanan, 12(3), 235-248.

Ostrom, E. (2003). How types of goods and property rights jointly affect collective action. Journal of Theoretical Politics, 15(3), 239-270. https:// doi.org/10.1177/0951692803015003002

Pirard, R., Petit, H., \& Baral, H. (2017). Local impacts of industrial tree plantations: An empirical analysis in Indonesia across plantation types.
Land Use Policy, 60 (2017), 242-253.https:// doi.org/10.1016/j.landusepol.2016.10.038

Priyatna, F.N. \& Kinseng, R.A., \& Satria, A. (2013). Akses dan strategi aktor-aktor dalam pemanfaatan sumber daya Waduk Djuanda. Jurnal Sosial Ekonomi Kelautan dan Perikanan, 8(1), 1-9.

Quizon A.B. (2013). Land governance in Asia: Understanding the debates on land tenure rights and land reforms in the Asian context. Rome: International Land Coalition.

Ribot, J.C. \& Peluso, N.L. (2003). A theory of access. Rural Sociology, 68(2), 153-181.

Schlager, E. \& Ostrom, E. (1992). Property-rights regimes and natural resources: A conceptual analysis. Land Economics, 68(3), 249-262.

Shivakoti, G. \& Ostrom, E. (2007). Facilitating decentralized policies for sustainable governance and management of forest resources in Asia. In Webb, E.L. \& Shivakoti, G. (Eds.), Decentralization, forests and rural communities. Policy outcomes in South and Southeast Asia. California: SEGA Publications.

Sinabutar, P., Nugroho, B., Kartodihardjo, H., \& Darusman, D. (2015). Kepastian hukum dan pengakuan para pihak hasil pengukuhan kawasan hutan negara di Provinsi Riau. Jurnal Analisis Kebijakan Kehutanan, 12(1), 27-40.

Suharti, S., Darusman, D., Nugroho, B., \& Sundawati, L. (2016). Kelembagaan dan perubahan hak akses masyarakat dalam pengelolaan hutan mangrove di Sinjai Timur, Sulawesi Selatan. Soladity: Jurnal Sosiologi Pedesaan, Agustus 20, 165-175.

Sylviani, \& Hakim, I. (2014). Analisis tenurial dalam pengembangan Kesatuan Pengelolaan Hutan (KPH): Studi kasus KPH Gedong Wani, Provinsi Lampung. Jurnal Penelitian Sosial dan Ekonomi Kehutanan, 11 (4), 309-322.

Tsujino, R., Yumoto, T., Kitamura, S., Djamaluddin, I. \& Darnaedi, D. (2016). History of forest loss and degradation in Indonesia. Land Use Policy, 57(2016), 335-347.

Zhang, D. (2016). Payments for forest-based environmental services: A close look. Forest Policy and Economics, 72 (2016), 78-84. 